\title{
Pengaruh Suasana Toko Terhadap Pembelian Impulsif (Kajian Empiris Pada Gerai Miniso di Kota Bandung)
}

\author{
M Setiawardani* \\ Jurusan Administrasi Niaga, Politeknik Negeri Bandung, Indonesia
}

\begin{abstract}
:
Store atmosphere is one of the important strategies in the field of marketing, especially for retail outlets because the atmosphere of the store can affect the emotions and feelings of customers to take action such as impulsive purchases. In addition, some Indonesian consumers have an unplanned character in purchasing (impulsive buying) caused by emotional and spontaneous attraction to a particular atmosphere, and often no longer involve rationality in the decision making process. This study aims to determine the effect of store atmosphere on impulsive buying made by customers from Miniso retail outlets in the city of Bandung. Store atmosphere is a store arrangement that is carried out in such a way as to create an overall emotional effect on customers through the five senses so that it can attract customers to come and finally make purchasing decisions. While this impulsive buying is the act of buying a product that is done suddenly or spontaneously. This study uses quantitative methods. The result is that there is a store atmosphere effect on impulsive buying in customers of Miniso retail outlets by $54 \%$ and the other $46 \%$ due to other factors. In addition, the store atmosphere created by Miniso outlets and impulsive buying by Miniso outlet customers is in the high category. However, Miniso still needs to improve the atmosphere of its stores such as aroma components and affective system management for customers.
\end{abstract}

Keywords: store atmosphere, impulsive buying, retail

\begin{abstract}
Abstrak:
Suasana toko adalah salah satu strategi penting di bidang pemasaran, terutama untuk gerai ritel karena suasana toko dapat memengaruhi emosi dan perasaan pelanggan untuk mengambil tindakan seperti pembelian impulsif. Selain itu, beberapa konsumen Indonesia memiliki karakter yang tidak terencana dalam pembelian (pembelian impulsif) yang disebabkan oleh ketertarikan emosional dan spontan ke atmosfer tertentu, dan seringkali tidak lagi melibatkan rasionalitas dalam proses pengambilan keputusan. Penelitian ini bertujuan untuk mengetahui pengaruh suasana toko terhadap pembelian impulsif yang dilakukan oleh pelanggan dari gerai ritel Miniso di kota Bandung. Suasana toko adalah pengaturan toko yang dilakukan sedemikian rupa untuk menciptakan efek emosional keseluruhan pada pelanggan melalui panca indera sehingga dapat menarik pelanggan untuk datang dan akhirnya membuat keputusan pembelian. Sedangkan pembelian impulsif ini adalah tindakan membeli produk yang dilakukan secara tiba-tiba atau secara spontan. Penelitian ini menggunakan metode kuantitatif. Hasilnya adalah bahwa ada efek atmosfer toko pada pembelian impulsif pada pelanggan outlet ritel Miniso
\end{abstract}


sebesar $54 \%$ dan $46 \%$ lainnya karena faktor lain. Selain itu, suasana toko yang diciptakan oleh gerai Miniso dan pembelian impulsif oleh pelanggan gerai Miniso termasuk dalam kategori tinggi. Namun, Miniso masih perlu meningkatkan suasana toko-tokonya seperti komponen aroma dan manajemen sistem afektif bagi pelanggan.

Kata Kunci: suasana toko, pembelian impulsif, ritel

\section{Pendahuluan}

Menurut Kementrian Perencanaan Pembangunan Nasional (2018) jumlah penduduk Indonesia pada tahun 2018 mencapai 265 juta jiwa. Sebelumnya, menurut Ansori (2014) dengan jumlah penduduk Indonesia yang sangat banyak, serta daya beli masyarakat yang tinggi menjadikan Indonesia sebagai pasar yang potensial baik bagi investor dalam maupun luar negeri. Salah satu industri yang banyak dimanfaatkan oleh investor asing yaitu industri ritel.

Menurut Pratomo (2018) meskipun pertumbuhan ritel di Indonesia mulai melambat. Namun, Indonesia tetap menjadi pasar potensial bagi peritel asing. Ironisnya, berbeda dengan peritel lokal yang mulai banyak yang gulung tikar, peritel asing justru semakin gencar menambah jumlah gerai produk mereka. Hal tersebut salah satunya disebabkan oleh psikologis masyarakat Indonesia terhadap brand global masih meningkat. Selain itu, banyak yang menyukai harga yang terjangkau namun kualitasnya baik (Widyastuti, 2018).

Salah satu jenis ritel yang menunjukan perkembangan yang cukup signifikan yaitu ritel yang berkonsep lifestyle. Menurut Richard (2018) gerai ritel yang berkonsep lifestyle good dari Asia Timur lebih kuat perkembangannya daripada ritel milik pengsusaha lokal. Adapun contoh dari ritel dengan konsep lifestyle good ini misalnya Daiso, Miniso, Kim so, Minigood, Kim So, Latt Liv dan Muji. Peritel dari brand-brand tersebut mampu membawa tren dari negara mereka pada masyarakat Indonesia yang mudah mengikuti mode yang sedang jadi tren setter. Semakin banyak peritel asing yang membuka gerainya di Indonesia, tentunya akan membuat persaingan bisnis mereka semakin ketat, oleh karena itu diperlukan suatu strategi agar dapat mengungguli para pesaingnya. Salah satu strategi penting dalam pemasaran yang berorientasi pada konsumen yaitu memperhatikan karakteristik dan perilaku konsumen yang menjadi target pemasaran.

Adapun karakteristik unik dan perilaku konsumen masyarakat Indonesia menurut Hernawan (2012) yaitu cenderung mempunyai memori otak yang pendek, berfikir dalam jangka pendek, gengsi, gagap teknologi, kurang peduli lingkungan dan suka bersosialisasi, lebih menyukai produk luar negeri, cenderung berfokus pada konteks bukan konten serta cenderung tidak memiliki perencanaan ketika belanja. Hal tersebut dikarenakan sebagian konsumen Indonesia memiliki karakter unplanned/tidak terencana. Pada umumnya mereka melakukan suatu tindakan/mengambil keputusan di waktu-waktu terakhir. Sehingga mayoritas konsumen Indonesia melakukan pembelian secara tidak direncanakan, mendadak dan on the spot, jenis pembelian tersebut umumnya dikenal dengan istilah "impulsive buying (pembelian impulsif)".

Karakter konsumen Indonesia yang tidak terencana serta tidak jarang melakukan pembelian secara mendadak dan on the spot sangat dimanfaatkan oleh peritel asing untuk memperoleh banyak konsumen yang akan membeli produknya. Salah satu contoh ritel asing yang memanfaatkan hal tersebut adalah ritel Miniso yang dikelola oleh PT Miniso Lifestyle Trading Indonesia. Miniso merupakan sebuah retail yang menjual berbagai perlengkapan fashion seperti alat kecantikan, produk make up, produk skin care serta berbagai perlengkapan umum lainnya. Produk dari ritel yang berasal dari negara Jepang ini sebagian besar merupakan produk yang menjadi lifestyle masyarakat Jepang yang umunya jarang dijumpai di retail lokal yang menjual produk serupa.

Salah satu strategi yang digunakan oleh retail Miniso adalah dengan penciptaan suasana toko yang menarik dan membuat nyaman konsumennya. Store atmosphere dapat digambarkan sebagai 
perubahan terhadap perencanaan lingkungan pembelian yang menghasilkan efek emosional positif yang dapat menyebabkan konsumen tertarik dengan produk yang ditawarkan sehingga melakukan tindakan pembelian. Menurut Resinda (2017), gerai Miniso memiliki konsep yang sederhana, natural, basic dan high quality. Di samping itu, produk-produk Miniso kebanyakan hadir dalam warna-warna pastel dengan kualitas dan desain yang manis namun tetap memiliki keunikan. Produk-produk tersebut dapat ditemukan dengan mudah karena semua produk selalu tersusun secara rapih berdasarkan kategori jenis produk di atas rak-rak kayu berdominasi warna putih dan coklat kayu. Selain itu kondisi gerai yang tidak terlalu luas namun tetap rapih, bercahaya terang, full $A C$ dan selalu bersih, serta adanya musik atau lagu yang diputarkan oleh petugas toko semakin membuat konsumen nyaman dan bergairah ketika berkunjung ke gerai Miniso dan membeli produk-produknya.

Salah satu strategi retail Miniso untuk karakteristik konsumen Indonesia yang tidak jarang melakukan pembelian tanpa direncanakan terlebih dahulu (impulsive buying) yaitu dengan menciptakan gairah konsumen untuk membeli dan mengkonsumsi sebuah produk tertentu. Karena, konsumen yang tertarik secara emosional seringkali tidak lagi melibatkan rasionalitas dalam proses pengambilan keputusan. berdasarkan hasil pra-penelitian diketahui 14 dari 25 orang mengunjungi gerai Miniso karena tertarik dengan suasana toko yang ditawarkan.

Berdasarkan pemaparan di atas, peneliti tertarik untuk mengetahui bagaimana penilaian store atmosphere (suasana toko) yang diberikan oleh konsumen Miniso dan bagaimana perilaku impulsive buying (pembelian impulsif) yang dilakukan oleh konsumen. Serta untuk mengetahui bagaimana pengaruh suasana toko terhadap pembelian implusif pada konsumen gerai retail Miniso di kota Bandung.

\section{Kajian Literatur}

\subsection{Store Atmosphere (Suasana Toko)}

Menurut Kotler dalam (Bohl: 2012:5 ), awalnya definisi store atmosphere disebut sebagai "buying environments" yang dirancang untuk menghasilkan efek emosional yang spesifik pada pembeli sehingga dapat meningkatkan probabilitas pembeliannya. Kotler (1974) menyatakan bahwa store amosphere merupakan alat pemasaran yang sangat relevan untuk pengecer dan kurang relevan untuk pabrikan maupun pedagang besar. Dimana, Seorang pengecer harus memberikan suasana dan lingkungan terbaik untuk tokonya. Terutama saat jumlah pengecer semakin meningkat serta persaingan antar pengecer pun semakin ketat.

Store atmosphere (suasana toko) dapat didefinisikan sebagai penataan toko yang dilakukan sedemikian rupa untuk menciptakan efek emosional secara menyeluruh pada konsumen melalui panca indera sehingga dapat menarik konsumen untuk datang dan akhirnya melakukan keputusan pembelian. Pernyataan tersebut merupakan kesimpulan dari beberapa definisi store atmosphere (suasana toko) yang telah dijelaskan oleh beberapa ahli berikut ini:

Pertama, definisi strore atmosphere menurut Kotler (1974:50) adalah usaha merancang lingkungan untuk menghasilkan efek emosional tertentu pada pembeli sehingga dapat meningkatkan probabilitas pembeliannya. Selain itu, store atmosphere tertentu dapat digambarkan dalam istilah-istilah sensoris. Kedua, menurut Chebat \& Minchon (2010:736) Store atmosphere mengacu pada estetika dan suasana toko. Isyarat atmosfer seperti wana, musik, pencahayaan, penciuman, kesesakan, tampilan jendela, serta penyimpanan barang. Ketiga, menurut Bohl (2012:5) store atmosphere yaitu semua faktor fisik objektif dari sebuah lingkungan ritel yang dapat dikendalikan oleh perusahaan untuk meningkatkan atau membatasi tindakan karyawan dan pelanggan.

Para peneliti memberikan gagasan yang berbeda-beda untuk dimensi store atmosphere (suasana toko). Pada intinya gagasan-gagasan tersebut tidak jauh berbeda satu sama lain. Karena, terdapat beberapa ahli yang menggunakan dimensi yang memiliki arti yang sama namun menggunakan istilah yang berbeda-beda. Namun, penelitian ini hanya menggunakan dimensi suasana toko yang dikemukakan oleh Kotler (1973-1974:51) dimana menurut kotler pengunjung toko dapat merasakan store atmosphere melalui saluran sensorik mereka termasuk pengelihatan, suara, aroma dan rasa. Dibawah ini merupakan penjelasan dari dimensi-dimensi tersebut:

a. Visual sense: Semua hal pada komponen ini dapat dinikmati langsung oleh indera pengelihatan seperti komponen toko berupa warna, kecerahan, ukuran, dan bentuk 
perlengkapan toko lainnya. Biasanya komponen-komponen tersebut menjadi faktor yang paling pertama dalam menarik konsumen untuk mengunjungi suatu toko.

b. Auditory sense: Komponen ini berupa bunyi-bunyian yang terdapat pada sebuah toko yang terdiri dari musik latar, iklan, audio di dalam toko, serta suara dari orang lain. Pada umumnya lagu yang diputar akan membuat konsumen lebih nyaman dan menkmati waktunya ketika berbelanja.

c. Olfactory sense: Komponen ini memanfaatkan indera penciuman manusia seperti aroma dan kualitas udara yang terdapat pada suatu toko. Hal yang paling utama yang perlu diperhatikan dalam komponen ini yaitu kualitas udara, karena kualitas udara yang kurang baik dapat disebabkan oleh sirkulasi udara yang kurang serta banyaknya orang yang berada di dalam toko pada waktu yang bersamaan. Tentunya hal tersebut akan membuat konsumen tidak nyaman dan segera meninggalkan toko.

d. Tactile sense: Komponen berikut ini dirasakan langsung oleh pengunjung toko dan terdiri dari bahan yang digunakan untuk lantai serta sensasi yang didapatkan ketika menyentuh komponen toko sepeti rak barang serta menyentuh material poduk yang di tawarkan oleh toko tersebut.

Store atmosphere memiliki kadar kepentingan yang berbeda-beda bagi semua pihak khususnya peritel. Kotler (1974) memberikan gagasan mengenai pentingnya store atmospher untuk sebuah toko ritel, yaitu:

1. Store atmosphere adalah suatu alat yang sangat penting untuk seorang pengecer

2. Store atmosphere menjadi suatu alat pemasaran yang penting karena jumlah outlet/gerai retail yang terus meningkat dan menyebabkan persaingan antar retail pun menjadi semakin ketat.

3. Store atmosphere adalah alat pemasaran yang lebih relevan dalam industri yang memiliki sedikit perbedaan produk maupun harga.

4. Store atmosphere menjadi suatu hal yang relevan ketika produk ditujukan untuk kelas sosial atau gaya hidup konsumen yang berbeda.

\subsection{Impulsive Buying (Pembelian Impulsif)}

Menurut Ünsalan (2016:578) pembelian impulsif menjadi suatu hal yang sangat penting karena dapat meningkatkan pendapatan yang tinggi untuk sebuah retail. Beberapa peneliti menemukan fakta bahwa sebagian besar pembeli pernah terlibat dalam pembelain implusif. Bahkan lebih dari sebagian konsumen dalam satu pusat perbelanjaan melakukan pembelian secara impulsif dan sepertiga dari semua pembelian pada departement store dilakukan hanya dengan dorongan hati yang tidak direncanakan dahulu sebelumnya. Hal ini menunjukan bahwa pembelian impulsif memiliki peranan yang sangat penting untuk pendapatan pengecer.

Studi mengenai teori pembelian impulsif dimulai pada akhir tahun 1940-an dengan studi awal mengenai "Consumer buying habbits". Namun, baru sejak awal 1950-an para ekonom, psikolog, dan sarjana perilaku konsumen dari seluruh dunia telah menyelidiki dan mencoba untuk menjelaskan makna teoretis dan praktis dari perilaku manusia impulsif. Sehingga para peneliti telah sepakat bahwa pembelian implusif pertama kali diidentifikasikan dalam literatur pemasaran oleh Clover pada tahun 1950 dengan judul jurnal "Relative Importance of Impulse-Buying in Retail Stores". Dalam studinya, Clover membuat penelitian pada 154 toko retail untuk menganalisis hubungan pembelian impulsif dan lingkungan ritel pada bulan Januari sampai Febuari 1948. Setelah penelitian tersebut, literatur mengenai pembelian impulsif semakin berkembang dan populer.

Adapun pengertian dari pembelian impulsif ini yaitu tindakan pembelian suatu produk yang dilakukan secara mendadak atau spontan. Dimana sebelumnya konsumen tidak memiliki rencana untuk melakukan pembelian tersebut, karena keinginan membeli produk yang muncul secara tiba-tiba ketika melihat secara langsung. Pada umumnya, tindakan tersebut mengesampingkan rasionalitas. Pernyataan tersebut merupakan kesimpulan yang dapat diambil dari beberapa teori mengenai definsi impulsive buying ang disampaikan oleh beberapa ahli di bawah ini. 
Pertama, gagasan yang diungkapkan oleh Clover (1950) yang menyatakan bahwa pembelian impulsif adalah keputusan pembelian yang terjadi secara spontan di toko dan konsumen tidak berencana untuk membeli produk sebelum berada di toko tersebut. Kedua menurut Rook (1987:191) pembelian impulsif terjadi ketika konsumen mengalami dorongan tiba-tiba, sering kali kuat bahkan terus menerus untuk membeli sesuatu dengan segera. Dorongan untuk melakukan pembelian tersebut terjadi secara hedonis dan dapat menghadirkan konflik emosional dalam diri. Ketiga menurut Khan et.al (2018:44) Pembelian impulsif terjadi ketika pelanggan melihat produk di toko dan perasaan batin sangat mendesak pelanggan untuk membeli dan membawanya ke dalam kepemilikan. Ketika pembeli membeli produk atau layanan tanpa rencana, pembelian seperti itu dikenal sebagai pembelian spontan.

Penelitian ini dilakukan dengan menggunakan dimensi impulsive buying (pembelian impulsif) yang merupakan gagasan dari Verplanken dan Aarts (1999) yang terdiri dari dimensi kognitif dan afektif. Dua dimensi tersebut merupakan jenis respons psikologis yang agak berbeda yang dapat dimiliki oleh konsumen dalam situasi belanja apapun. Meskipun afektif dan kognitif berbeda namun keduanya dapat saling mempengaruhi satu sama lain. Afektif mengacu pada tanggapan perasaan, sedangkan kognitif terdiri dari mental dan tanggapan pemikiran. Sistem afektif dan kognitif seorang konsumen dapat aktif disetiap saat dan lingkungan, akan tetapi banyak aktivitas yang dapat terjadi tanpa banyak melibatkan kedua aspek tersebut seperti yang terjadi ketika seseorang melakukan pembelian impulsif.

Pembelian impulsif dapat diakibatkan oleh berbagai faktor yang berbeda pada masing-masing individu. Hal ini membuat terdapat beberapa jenis pembelian impulsif menurut Stern (1962:59):

1. Pure Impulse Buying : Jenis yang paling mudah dibedakan adalah pembelian impuls murni. Adapun maksud dari jenis pembelian impulsif ini adalah pembelian yang dilakukan tanpa adanya rencana sama sekali dan spontan.

2. Reminder Impulse Buying: Reminder impulse buying terjadi ketika seorang pembelanja melihat suatu barang dan ingat bahwa persediaan di rumah habis atau sedikit.

3. Suggestion Impulse Buying: Saran pembelian terjadi ketika pembeli melihat produk untuk pertama kalinya dan memvisualisasikan kebutuhan untuk itu, meskipun dia tidak memiliki pengetahuan sebelumnya tentang item tersebut.

4. Planned Impulse Buying: Pembelian spontan yang direncanakan terjadi ketika pembelanja memasuki toko dengan beberapa pembelian spesifik dalam pikiran, tetapi dengan harapan dan niat untuk melakukan pembelian lain yang bergantung pada harga spesial, penawaran kupon, dan sejenisnya

\subsection{Hubungan Store Atmosphere dengan Impulsive Buying}

Telah cukup banyak literature penelitian terdahulu yang membahas hubungan store atmosphere (suasana toko) dan impulsive buying (pembelian impulsif) pada toko retail yang menjual berbagai produk maupun jasa. Dari beberapa penelitian yang ditemukan, dapat disimpulkan bahwa suasana yang terdapat dalam sebuah toko dapat mempengaruhi bahkan menciptakan perilaku pembelian impulsif pada konsumennya meskipun penelitian-penelitian tersebut menggunakan teori dan alat pengukuran yang berbeda-beda.

Pertama, hasil penelitian yang dilakukan oleh Sinha dan Kant (2015) mengungkapkan bahwa suasana toko melalui komunikasi visual, pencahayaan, warna, musik, dan aroma untuk merangsang respons persepsi dan emosi pelanggan serta pada akhirnya akan mempengaruhi perilaku pembelian konsumen. Hasil dari penelitian ini menunjukkan bahwa atmosfer toko membawa perasaan psikologis dalam pikiran pelanggan yang memasuki toko. Penglihatan, suara, bau, tampilan, warna, manekin di toko ritel semuanya berkontribusi terhadap persepsi pelanggan.

Penelitian berikutnya dilakukan oleh Ukpabi et.al (2015) dengan hasil bahwa peningkatan upaya untuk mempercantik komponen atmosfer toko mengarah pada peningkatan pembeli impulsif. Sementara keindahan eksternal toko menarik pembeli ke toko seperti yang ditunjukkan dalam penelitian ini, suasana interior umum seperti musik, cahaya, warna dan suhu, dikombinasikan dalam campuran yang memadai, menciptakan suasana santai yang mendorong pembeli untuk tinggal lebih lama. Display toko membantu mengingatkan pembeli barang untuk membeli dan meningkatkan penjelajahan karena tata letak toko meningkatkan gerakan di sekitar toko. 
Penelitian ketiga, yaitu penelitian yang dilakukan oleh Jiang dan Liu (2014), dan hasilnya mengungkapkan bahwa stimulus suasana seperti iklan yang menarik, demosntrasi informasi diluar toko, informasi diskon, arah produk serta tenaga penjual layanan yang profesional dapat menciptakan rasa kesenangan dan gairah pada pengunjung toko yang akhirnya dapat memicu pembelian impulsif mereka di toko-toko elektronik yang diteliti.

Penelitian ini membahas bagaimana suasana toko gerai Miniso dapat berpengaruh terhadap perilaku pembelian impulsif yang dilakukan oleh konsumennya. Khususnya mengenai efek emosional yang dapat ditimbulkan dari suasana toko melalui berbagai komponen visual, auditory, tactile dan olfactory sense yang pada akhirnya dapat menyebabkan seorang konsumen melakukan pembelian impulsif.

\subsection{Hipotesis Penelitian}

Adapun hipotesis dalam penelitian ini, yaitu:

$\mathrm{H}_{\mathrm{a}}$ : Adanya pengaruh store atmosphere terhadap implusive buying pada pelanggan gerai Miniso di Kota Bandung.

$\mathrm{H}_{0}$ : Tidak adanya pengaruh store atmosphere terhadap implusive buying pada pelanggan gerai Miniso di Kota Bandung.

\section{Metode Penelitian}

Metode penelitian yang digunakan dalam penelitian ini yaitu metode pendekatan kuantitatif, untuk meneliti hubungan suasana toko dan pembelian impulsif. Namun, jumlah konsumen Minsio di kota Bandung atau jumlah populasi dalam penelitian ini tidak diketahui. Adapun teknik pengambilan sample yang digunakan dalam penelitian ini adalah teknik non probability sampling dengan jumlah sampel sebanyak 117 orang konsumen gerai Minsio di kota Bandung. Sedangkan metode pengambilan sampel peda penelitian ini purposive sampling dimana konsumen yang berkunjung secara langsung ke gerai ritel Miniso di kota Bandung dan melakukan pembelian minimal satu kali. Di samping itu, metode analisis data yang pergunakan adalah metode analisis statistik deksriptif, uji asumsi klasik, analisis korelasi sederhana, analisis regresi linier sederhana, dan uji hipotesis.

Penelitian ini akan menggunakan skala pengukuran likert yang digunakan untuk mengukur respon subjek ke dalam lima poin skala dengan interval yang sama. Penelitian ini akan menggunakan instrumen store atmosphere yang diadaptasi dari Han, Kuang, Low \& Yap (2011) dan Vijay (2013) dalam Hussain dan Ali (2015) sebagai alat untuk mengukur store atmosfer pada gerai Miniso di Kota Bandung. Adapun dimensi-dimensi pada instrumen ini adalah cleanliness, music, scent, temperature, lighting, colour, serta display/layout store. Sedangkan untuk variabel impulsive buying akan menggunakan instrumen impulsive buying tendency scale yang diadaptasi dari penelitian yang dilakukan oleh Verplanken dan Heradabi (2001). Instrumen ini hanya terdiri dari dua dimensi yaitu dimensi yaitu item kognitif dan item afektif.

\section{Hasil dan Pembahasan}

Penelitian ini dilakukan dengan cara menyebarkan kuisioner kepada 117 orang konsumen gerai ritel Miniso di Kota Bandung dengan kriteria pelanggan yang pernah berkunjung secara langsung dan melakukan pembelian minimal satu kali di gerai ritel Miniso.

Dari responden penelitian sebanyak 117 orang diketahui data responden berdasarkan jenis kelamin, usia serta jumlah penghasilan perbulan. Pertama, terdapat $67 \%$ konsumen yang berjenis kelamin perempuan dan $22 \%$ lainnya merupakan konsumen berjenis kelamin laki-laki. Selanjutnya, terdapat 12\% konsumen berumur $<20$ tahun, 21\% konsumen berumur 20-22 tahun, 29\% konsumen berumur 22-24 tahun, 31\% konsumen berumur 24-26 tahun, dan sisanya yaitu 7\% konsumen berumur $>26$ tahun. Berikutnya, data responden yang dikelompokan berdasarkan jumlah penghasilan perbulan konsumen. Pertama, terdapat 4\% konsumen yang berpenghasilan <Rp. 1.000.000/bulan. 26\% konsumen berpehangsilan Rp. 1.0000.000-Rp.2.000.000/bulan,41\% berpenghasilan Rp.2.000.000Rp. 3.000.000/bulan, dan terakhir terdapat 29\% konsumen yang berpehangsilan >Rp 3.000.000/bulan. 


\subsection{Store Atmosphere (Suasana Toko)}

Berikut ini merupakan hasil analiss deskriptif mengenai variabel store atmosphere (suasana toko) yang terdapat pada gerai ritel Miniso di kota Bandung. Pada kolom berikutnya terdapat tabel analisis deksriptf variabel ini:

Tabel 1. Analis Deskriptif Variabel Store Atmosphere

\begin{tabular}{|l|c|c|c|c|c|}
\hline & N & Min & Max & Mean & $\begin{array}{c}\text { Std. } \\
\text { Deviation }\end{array}$ \\
\hline Visual Sense & 117 & 1 & 5 & 4,15 & 0,796 \\
Auditory Sense & 117 & 1 & 5 & 3,62 & 0,859 \\
\hline Olfactory Sense & 117 & 1 & 5 & 3,28 & 1,03 \\
Tactile Sense & 117 & 2 & 5 & 4,09 & 0,727 \\
Variabel Store Atmosphere & 117 & 1 & 5 & 3,80 & 0,853 \\
Valid N (listwise) & 117 & & & & \\
\hline
\end{tabular}

Berdasarkan Tabel 1 dapat diketahui bahwa nilai rata-rata variabel store atmosphere (suasana toko) yaitu 3,80 dan nilai tersebut termasuk dalam kategori tinggi. Hal ini berarti, suasana toko yang diberikan oleh gerai Miniso mendapatkan nilai tinggi atau sudah dinilai baik oleh para konsumennya. Selain itu, pernyataan-pernyataan tersebut disetujui oleh sebagian besar responden, hal ini berdasarkan nilai standar deviasi yang nilainya kurang dari nilai mean yaitu 0,853 dengan standar koefisien variasi sebesar 22,4\%. Adapun arti dari hal tersebut yaitu sebagian besar responden memberikan jawaban yang cukup beragam pada setiap instrumen di variabel store atmosphere (suasana toko). Mayoritas nilai mean pada masing-masing dimensi termasuk dalam kategori tinggi, karena nilai mean pada dimensi olfactory sense hanya mendapatkan nilai mean sebesar 3,28 dan hanya termasuk dalam kategori cukup.

Visual sense yang dimiliki oleh gerai Miniso di kota Bandung dinilai baik/tinggi oleh konsumennya karena dimensi ini memiliki nilai rata-rata sebesar 4,15 dan juga menjadi dimensi store atmosphere yang memiliki nilai mean tertinggi. Visual sense ini dapat berupa pencahayaan, dekorasi dan warna. Adapun visual sense yang menjadi ciri khas dari gerai Miniso yaitu gerainya yang bercahaya terang dan di dominasi oleh warna putih, warna natural seperti warna kayu dan warna pastel pada beberapa tempat. Dimana warna-warna tersebut dapat berpengaruh terhadap suasana dan emosi konsumennya seperti tertarik untuk mengunjungi toko, membuat konsumennya nyaman berada di gerai, membuat konsumennya tertarik membeli suatu produk tertentu dan membuat para pembeli mengenali retail Miniso dengan mudah. Bahkan, mayoritas konsumen melakukan kunjungan kembali ke beberapa gerai Miniso karena merasa tertarik dengan komponen visual gerai yang diberikan oleh ritel Miniso.

Selanjutnya, auditory sense yaitu komponen suasana toko yang berkaitan dengan bunyi-bunyian yang dapat didengarkan ketika berada didalam gerai Miniso. Dimensi auditory sense ini memiliki nilai mean sebesar 3,62 dan termasuk dalam kategori tinggi atau baik. Hal ini dapat disebabkan karena beberapa hal seperti suara pengunjung gerai yang tidak bising, lokasi gerai yang berada dalam gedung pusat perbelanjaan modern dan pegawai gerai yang memutar musik atau lagu terbaru dan terkini untuk pengunjung. Namun, berdasarkan pendapat sejumlah pengunjung terkadang pegawai gerai tidak memutarkan musik atau lagu apapun bahkan ketika gerai sedang ramai. Hal tersebut tentunya membuat pengunjung cepat merasa bosan dan kurnag menikmati waktunya di gerai Miniso. Kendati demikian, komponen auditory sense memang dapat membuat pelanggan lebih banyak berbelanja. Hal tersebut selaras dengan Morrison (2016) yang mengatakan bahwa musik dapat mempengaruhi emosi karena musik dapat mengingatkan seseorang terhadap suatu memori tertentu yang dapat menciptakan berbagai perasaaan. Selain itu, musik pun dapat membuat seseorang beraktivitas lebih cepat atau lambat dan lebih menikmati aktivitas tersebut.

Dimensi ketiga pada variabel store atmosphere yaitu olfactory sense, dimensi ini berkaitan dengan komponen berupa aroma yang terdapat pada sebuah toko. Dimensi ini hanya memiliki nilai mean sebesar 3,28 dan termasuk dalam kategori cukup. Selain itu, dimensi ini menjadi dimensi yang memiliki nilai mean paling rendah dibandingkan nilai mean pada dimensi lain. Beberapa konsumen menjelaskan bahwa sirkulasi udara yang terdapat pada gerai Miniso dinilai sudah bagus. Namun, 
aroma wewangian yang terdapat pada gerai Miniso masih dinilai kurang tercium aromanya. Sedangkan menurut Mowen dan Minor (2002:25) konsumen lebih sering kembali mengunjungi toko yang diberi wewangian dan menganggap barang-barang yang dijual di toko tersebut memiliki kualitas lebih baik daripada barang-barang serupa di toko lain yang tidak diberikan wewangian.

Dimensi terakhir pada variabel store atmosphere dalam penelitian ini yaitu tactile sense, dimensi ini berkaitan dengan komponen suasana toko yang langsung dapat disentuh oleh konsumen. Tactile Sense dapat dibagi ke dalam dua jenis yaitu tactile sense yang terdapat pada peralatan atau material toko dan tactile sense yang terdapat pada barang-barang yang pasarkan. Dimensi ini memiliki nilai mean sebesar 4,09 dan termasuk dalam kategori tinggi. Hal ini dapat disebabkan karena material miniso yang aman ketika digunakan. Bukan hanya material yang terdapat dalam perlengkapan toko. Namun juga material yang digunakan dalam produk-produk Miniso pun dinilai bagus oleh konsumennya. Bahkan, diantara pihak retail Miniso secara khusus menyediakan barang-barang sampel yang dapat dicoba terlebih dahulu oleh konsumen sebelum membeli barang tersbut. Di samping itu, menurut Citrin et.al (2003:917) menyentuh produk dapat menciptakan dampak menciptakan dampak positif bagi konsumen. Disamping itu, menurut penelitian yang dilakukan oleh McCabe dan Nowlis (2003:433) sebagian besar konsumen memiliki keinginan untuk melihat produk secara langsung dan mendapatkan informasi tentang produk tersebut dengan cara memegang dan menyentuh produk tersebut.

\subsection{Impulsive Buying (Pembelian Impulsif)}

Berdasarkan Tabel 2, variabel impulsive buying (pembelian impulsif) ini memiliki nilai rata-rata sebesar 4,02 dan berada pada interval 3,40-4,19 yaitu di kategori tinggi. Di samping itu, adapun nilai standar standar deviasi pada variabel ini adalah 0,840 dan nilai koefisien variasinya sebesar 20,89\% yang artinya jawaban responden pada pernyataan-pernyataan di variabel buying impulsive dapat dikatakan beragam. Maka, dapat disimpulkan bahwa buying impulsif yang dilakukan oleh konsumen gerai Miniso dapat dikatakan tinggi. Dari dua dimensi yang menjadi faktor dalam pembelian implusif, dimensi affective items memiliki nilai rata-rata yang lebih rendah yaitu hanya 3,96 dan dimensi lainnya yaitu cognitive items memiliki nilai rata-rata sebesar 4,09 kendati demikian kedua dimensi ini masuk ke dalam interval 3,40-4,19 yang artinya masuk ke dalam kategori tinggi. Di samping itu, cognitive dan affective adalah dua jenis respon psikologis yang cukup berbeda yang dapat dimiliki oleh seorang konsumen dalam situasi belanja apapun. Namun, kedua aspek tersebut saling mempengaruhi dan dipengaruhi satu sama lain. Affective mengacu pada tanggapan dan perasaan seseorang, sedangkan cognitive mengacu pada mental (pemikiran), logika serta tanggapan seseorang.

Tabel 2. Analisis Deskriptif Variabel Impulsive Buying

\begin{tabular}{|l|c|c|c|c|c|}
\hline & $\mathrm{N}$ & Minimum & Maximum & Mean & $\begin{array}{c}\text { Std. } \\
\text { Deviation }\end{array}$ \\
\hline Cognitive items & 117 & 1 & 5 & 4,09 & 0,839 \\
\hline Affective item & 117 & 2 & 5 & 3,96 & 0,840 \\
Variabel Buying & 117 & 1 & 5 & 4,02 & 0,840 \\
Implusive & 117 & & & & \\
Valid N (listwise) & 117 & & &
\end{tabular}

Dimensi pertama pada variabel ini yaitu cognitive items (Item Kognitif), dimensi ini berkaitan dengan akal pikiran, logika serta tanggapan dari orang lain. Dimensi ini memiliki nilai mean sebesar 4,09 dan termasuk dalam kategori tinggi. Hal ini berarti, mayoritas konsumen gerai Miniso menggunakan akal sehat, logika serta pikiran ketika mengunjungi gerai Miniso dan melakukan pembelian produk. Menurut Coley (2002:30) Cognitive items seseorang dapat didasari oleh pengalaman pribadi maupun orang lain untuk dapat mengevaluasi beberapa produk dalam memenuhi kebutuhannya. Hal tersebut dapat berupa pemikiran mengenai jumlah biaya yang harus di keluarkan, banyaknya produk yang harus dibeli, bagaimana cara pembayarannya. Beberapa konsumen kerap melakukan evaluasi dan pertimbangan terlebih dahulu sebelum membeli produk Miniso, bahkan hingga dapat tinggal lebih lama di gerai Miniso hanya karena melakukan pertimbangan tersebut. 
Dimensi kedua pada variabel ini yaitu affective items (afektif), dimensi ini mengacu pada alasan emosional dan perasaaan seseorang. Disamping itu, dimensi ini memiliki nilai mean sebesar 3,96 dan termasuk dalam kategori tinggi. Ini berarti, konsumen Miniso pun menggunakan alasan emosional dan perasaannya ketik amelakukan pembelian produk di gerai Miniso. Menurut Coley (2002:31) pada umumnya konsumen yang lebih banyak menggunakan aspek afektifnya ketika berbelanja cenderung melakukan pembelian karena menginginkan barang tersebut meskipun tidak terlalu dibutuhkan. Selain itu, konsumen tersebut pun cenderung bersifat konsumtif dan hedonisme.

\subsection{Pengaruh Store Atmosphere Terhadap Impulsive Buying}

Berdasarkan hasil penelitian yang dilakukan pada konsumen gerai ritel Miniso di Kota Bandung, diperoleh hasil regresi linier sederhana.

Tabel 3. Hasil Regresi Linier Sederhana

\begin{tabular}{|c|r|r|r|r|r|}
\hline \multirow{2}{*}{ Model } & \multicolumn{2}{|c|}{$\begin{array}{c}\text { Unstandardized } \\
\text { Coefficients }\end{array}$} & $\begin{array}{r}\text { Standardiz } \\
\text { ed } \\
\text { Coefficient } \\
\mathrm{s}\end{array}$ & $\mathrm{t}$ & \multirow{2}{*}{ Sig. } \\
\cline { 2 - 5 } & \multicolumn{1}{|c|}{$\mathrm{B}$} & Std. Error & \multicolumn{1}{c|}{ Beta } & & \\
\hline \multirow{2}{*}{1 (Constant) } & 10,586 & 2,228 & & 4,751 & 0,00 \\
Store_Atmosphere & 0,465 & 0,04 & 0,735 & 11,627 & 0,00 \\
\hline
\end{tabular}

Berdasarkan tabel di atas, dapat diketahui bahwa jika store atmosphere (suasana toko) meningkat, maka impulsive buying (pembelian impulsif) akan meningkat. Penyataan ini berdasrkan hasil dari model persamaan regresi pada Tabel 3 yaitu $Y=10,586+0,465 X$. Dari persamaan regresi linier sederhana tersebut, diketahui nilai konstanta sebesar 10,568 yang menjelaskan bahwa setiap penambahan satu angka pada suasana toko dengan koefisien regresi bernilai positif, maka pembelian impulsif pun akan meningkat sebesar 0,465. Ini artinya, apabila suasana toko di gerai Miniso dapat ditingkatkan, maka pembelian impulsif yang dilakukan konsumen pun akan meningkat.

Tabel 4. Koefisien Determinasi

\begin{tabular}{|c|c|c|c|c|}
\hline Model & $\mathrm{R}$ & R Square & $\begin{array}{c}\text { Adjusted } \\
\text { R Square }\end{array}$ & $\begin{array}{c}\text { Std. Error } \\
\text { of the } \\
\text { Estimate }\end{array}$ \\
\hline 1 &, $735^{\mathrm{a}}$ & 0,54 & 0,536 & 2,885 \\
\hline
\end{tabular}

Tabel diatas menunjukan bahwa terdapat hubungan positif yang kuat antara dua variabel penelitian yaitu store atmosphere (suasana toko) dengan impulsive buying (pembelian impulsif). Hal ini berdasarkan nilai R yang diperoleh yaitu 0,735. Dimana menurut Sugiyono (2013) apabila nilai R berada pada interval 0,60-0,799 maka termasuk dalam kategori kuat. Di samping itu, hasil dari regresi linier sederhana menunjukkan nilai R Square atau koefisien determinasi sebesar 0,540 atau 54\%. Angka tersebut menunjukan bahwa suasana toko yang diciptakan oleh ritel Miniso mempunyai pengaruh sebesar 54\% terhadap pembelian impulsif yang dilakukan oleh konsumen ritel tersebut.

Konsumen gerai ritel Miniso di Kota Bandung terpengaruh oleh store atmosphere (suasana toko) yang diciptakan oleh ritel Miniso yang dapat membuat mereka melakukan impulsive buying (pembelian impulsif). Hal tersebut dikarenakan emosi, perasaan maupun mood konsumen yang terpengaruh oleh berbagai komponen store atmosphere gerai Miniso seperti warna, pencahayaan, musik, aroma gerai, dan tekstur. Namun, sebelum mereka melakukan transaksi pembelian di kasir, sistem afektif dan kognitf mereka bekerja untuk membuat suatu keputusan terlebih dahulu. Terdapat konsumen yang lebih mempertimbangkan dan melakukan evaluasi produk secara seksama seperti mengenai dampak positif dan negatif jika membeli produk tersebut atau produk dalam jumlah tertentu. Sedangkan konsumen lainnya lebih mengutamakan sistem afektifnya dalam berbelanja, konsumen tersebut tidak terlalu mempertimbangkan dampaknya jika membeli suatu produk karena cenderung lebih mengikuti keinginan, perasaan dan emosi.

Pengelolaan store atmosphere (suasana toko) ritel Minsio yang tepat, terbukti dapat membuat konsumen melakukan pembelian impulsif atau pembelian yang dilakukan tanpa adanya perencanaan 
terlebih dahulu. Disadari maupun tidak, konsumen terpengaruh oleh suasana yang didapatkan ketika mereka mengunjungi gerai Minsio. Bahkan, tidak sedikit konsumen yang melakukan kunjungan kembali ke gerai Miniso. Adapun alasan pertama mayoritas konsumen mengunjungi gerai Miniso, karena mereka tertarik dengan visual gerai yang didominasi oleh warna putih, tertata rapih dan transparan. Seorang konsumen dapat menghabiskan waktu sekitar 10-30 menit untuk berada di gerai tersebut tergantung dari luas masing-masing gerai. Berdasarkan hasil pengamatan, pada umumnya seorang konsumen akan mengelilingi rak produk untuk melihat produk-produk yang ditawarkan sembari menikmati suasana toko yang diberikan, pada tahapan ini juga emosi dan perasaan konsumen mulai terpengaruh oleh suasana yang ada. Hingga pada akhirnya timbul suatu keinginan untuk membeli suatu produk Miniso meskipun pada awalnya konsumen tersebut tidak memiliki rencana untuk membeli produk Miniso.

Selain dapat membuat konsumen baru tertarik untuk mengunjungi gerai, store atmosphere pada gerai Miniso pun dapat membuat konsumen melakukan kunjungannya kembali. Adapun salah satu alasannya yaitu karena mereka menyukai suasana toko yang diberikan, mereka merasakan suatu pengalaman yang berbeda ketika mengunjungi gerai Miniso dibandingkan dengan gerai-gerai lain. Di samping itu, menurut beberapa konsumen yang menjadi responden dalam penelitian ini berkata bahwa mereka sering menyempatkan diri tanpa adanya perencanaan dahulu untuk mengunjungi gerai Miniso ketika mereka sedang berada di pusat perbelajaan modern. Selain itu, mayoritas konsumen pernah mengunjungi gerai Miniso di beberapa lokasi pusat perbelanjaan.

\section{Kesimpulan dan Saran}

\subsection{Kesimpulan}

Berdasarkan hasil penelitian yang telah dilakukan pada konsumen gerai ritel Miniso di Kota Bandung, maka dapat disimpulkan:

1. Store atmosphere (suasana toko) yang diciptakan oleh ritel Miniso sudah dinilai baik/tinggi oleh mayoritas konsumennya. Namun, masih terdapat unsur suasana toko yang perlu ditingkatkan kembali seperti olfactory sense, yaitu berupa aroma wewangian yang dinilai kurang kuat oleh konsumennya.

2. Impulsive buying (pembelian impulsif) yang dilakukan oleh konsumen gerai ritel Miniso tergolong tinggi baik dari sistem affective maupun sistem cognitive. Namun, terdapat beberapa hal yang sebaiknya diperbaiki oleh konsumen ritel Miniso seperti pengelolaan emosi dan perasaan yang merupakan hasil pengaruh dari suasana toko yang diberikan oleh ritel Miniso.

3. Store atmosphere (suasana toko) berpengaruh terhadap keputusan impulsive buying (pembelian impulsif) yang dilakukan oleh konsumen gerai ritel Miniso. Hal ini ditunjukan dengan adanya pengaruh suasana toko terhadap pembelian implusif sebesar 54\%.

\subsection{Saran}

Saran berdasarkan hasil penelitian ini adalah:

1. Karena komponen olfactory sense mendapatkan nilai rata-rata paling rendah dibandingkan komponen lainnya, maka sebaiknya peningkatkan komponen suasana toko terlebih dahulu difokuskan kepada olfactory sense khususnya aroma wewangian yang kurang tercium di dalam gerai ritel Miniso. Sebaiknya, pihak ritel Miniso memberikan wewangian yang lebih kuat aromanya dan disimpan di beberapa lokasi yang dapat menyebarkan aroma tersebut ke setiap sudut gerai. Karena, komponen ini pun dapat mempengaruhi emosi konsumennya, dimana konsumen akan merasa lebih nyaman berada di dalam gerai dan dapat melakukan kunjungan kembali ke gerai Miniso tersebut.

2. Karena nilai rata-rata affective konsumen tergolong tinggi ketika melakukan pembelian di gerai Miniso, maka sebaiknya setiap konsumen mampu dan bijak dalam mengelola emosi, perasaan dan keinginannya untuk membeli suatu produk. Alangkah lebih baik, jika seorang konsumen mempertimbangkan dan melakukan evaluasi terlebih dahulu sebelum membeli suatu barang. Serta lebih dapat membedakan mana barang yang dibutuhkan dan mana barang yang hanya diinginkan. Hal ini bertujuan untuk menghindari sifat konsumtif dan hedonisme dan mencegah adanya penyesalan dimasa yang akan datang. 
3. Karena pengaruh store atmosphere (suasana toko) terhadap buying implusive (pembelian implusif) konsumen gerai ritel Miniso sebesar 54,0\% maka sebaiknya pihak manajemen ritel Miniso melakukan beberapa perbaikan dan peningkatan pada komponen-komponen store atmosphere yang diberikan untuk konsumen. Hal tersebut pun dapat berpengaruh terhadap perilaku pembelian impulsif yang dilakukan oleh konsumen.

\section{Daftar Pustaka}

Ansori, M. (2014, 10 08). Minim Wirausahawan, Pasar Indonesia Dikuasai Produk Asing. Retrieved from Harian Ekonomi Neraca: http://www.neraca.co.id/article/46257/minim-wirausahawan-pasarindonesia-dikuasai-produk-asing

Bohl, P. (2012). The effects of store atmosphere on shopping behaviour-A literature review. Budapest: Corvinus University of Budapest.

Chebat, J., \& Minchon, R. (2003). Impact Of Ambient Odors On Mall Shoppers' Emotions, Cognition, and Spending A Test Of Competitive Causal Theories. Jurnal of Business research. , 529-539.

Citrin, A. V., Stem Jr, D. E., Spanngerberg, E. R., \& Clark, M. J. (2003). Consumer need for tactile input: An internet retailing challenge. Journal of Business Research Vol. 56 Issue 11, 915-922.

Clover, V. T. (1950). Relative Importance of Impulse-Buying in Retail Stores. The Journal of Marketing, 66-70.

Coley, A. L. (2002). Affective and Cognitive Processes Involved in Impluse Buying. Georgia, Athena: The University of Georgia.

Foster, B. (2008). Manajemen Ritel. Bandung: Alfabeta.

Hernawan, A. (2012). Komunikasi Pemasaran. Jakarta: Erlangga.

Hussain, R., \& Ali, M. (2015 ). Effect of Store Atmosphere on Customer Purchase Intention. International Journal of Marketing Studies Vol. 7 No. 2 , 35-43.

Jiang, P., \& Liu, X. (2014). The Influence of Store Atmosphere on Shoppers'Impulse Purchasing Behavior. Swedia: School of Economics and Management Lund University .

Kementrian Perencanaan Pembangunan Nasional (Bapenas). (2018, Mei 18). 2018, Jumlah Penduduk Indonesia Mencapai 265 Juta Jiwa. Retrieved from katadata.co.id: https://databoks.katadata.co.id/datapublish/2018/05/18/2018-jumlah-penduduk-indonesiamencapai-265-juta-jiwa

Khan, N., Hui, L. H., Chen, T. B., \& Hoe, H. Y. (2016). Impulse Buying Behaviour of Generation Y in Fashion Retail. International Journal of Business and Management; Vol. 11, No. 1, 144-151.

Kotler, P. (1974). Atmospherics as a marketing tool. Journal of retailing, 48-64.

McCabe, D. B., \& Nowlis, S. (2003). The effect of examining actual products or product descriptions on consumer preference,. Journal of Consumer Psychology Vol. 13 No. 4, 431-439.

Morrison, L. (2016, July 21). Musik yang mendorong kita lebih banyak berbelanja. Retrieved from BBC News Indonesia: https://www.bbc.com/indonesia/vert_cap/2016/07/160719_vert_cap_efek_musik_bisnis

Mowen, J., \& Minor, M. (2002). Perilaku Konsumen. Jakarta: Erlangga.

Pratomo , Y. (2018, January 04). Ritel Lambat Tumbuh, Peritel Asing Masih Anggap Indonesia Tambang Emas. Retrieved from Ayoberita: http://ayooberita.com/berita-ritel-lambat-tumbuhperitel-asing-masih-anggap-indonesia-tambang-emas

Resinda. (2017, October 25). Miniso Mini Tokyo Store. Retrieved from Issuu: https://issuu.com/resinda/docs/resinda_oct_2017

Richard, M. (2018, July 03). Ritel Gaya Hidup Asal Asia Timur Semakin Merajalela, Inikah penyebabnya? Retrieved from Industri Bisnis: http://industri.bisnis.com/read/20180703/12/812383/ritel-gaya-hidup-asal-asia-timur-semakinmerajalela-inikah-penyebabnya

Rook, D. W. (1987). The Buying Impulse. The Journal of Consumer Research Vol 14, 189-199.

Sinha, R. B., \& Kant, R. (2015). Effect of store atmospherics on customer buying behaviour. Asian Journal of Home Science Vol. 10 Issue 2 , 386-394.

Stern, H. (1962). The Significance of Impluse Buying Today. Journal of Marketing, 59-62.

Sugiyono. (2013). Metodologi Penelitian Kuantitatif, kualitatif dan R\&D. Bandung: Alpabeta. 
Ukpabi, D. C., Enyindah, C. W., Gwere, J. N., \& Ejire, S. (2015). Store Atmosphere And Impulse Buying: An Empirical Study Of Shoppers In Port Harcourt.Proceedings of The International Academic Conference for Sub-Sahara African Transformation \& Development Vol 3 No. 7.

Ünsalan , M. (2016). Stimulating Factors Of Impulse Buying Behavior: A Literature Review.Gazi Üniversitesi İktisadi ve İdari Bilimler Fakültesi Dergisi, 572-593.

Verpalnken, B., \& Aarts, H. (1999). Habit, Attitude, and Planned Behaviour: Is Habit an Empty Construct or an Interesting Case of Goal-directed Automaticity? European Review of Social Pyschology, 101-134.

Verplanken, B., \& Herabadi, A. (2001). Individual Differences in Impluse Buyin Tendency Feeling and no Thinking. European Journal of Pesonality Eur. J. Pers, 15: S71-283, 71-83.

Widyastuti, R. Y. (2018, January 23). Ini Brand Retail Internasional yang Bakal Ekspansi di 2018. Retrieved from Tempo.co: https://bisnis.tempo.co/read/1053146/ini-brand-retail-internasionalyang-bakal-ekspansi-di-2018

*Email korespondensi:

mayaswardani@gmail.com 